Jurnal Teknologi, 51(E) Dis. 2009: 111-121

(C) Universiti Teknologi Malaysia

\title{
UNDERSTANDING FORM-FUNCTION RELATIONSHIP: THE CASE OF WRITTEN TEXTS OF AN ELECTRONICS MANUFACTURING FIRM
}

\begin{abstract}
ANIE ATTAN ${ }^{1}$
Abstract. Writing documents for the workplace differs from that for an academic setting. Although much has been researched about meeting the needs of employers and employees; there is, yet, adequate research and thick descriptions to inform readers about how participants in the workplace negotiate meaning and how texts play a role in that respect. It has been argued that apart from knowledge of audience, purpose and mechanics of writing, the writer in the workplace should also be aware of the work culture of the organization he is in. Shared values, beliefs, expectations, norms and language are believed to have an influence in the shaping of texts. Each organization, it is said, to has its own specific set of goals and cultures; and texts are said to have had a role in the fulfillment of those goals. This attempt is part of a larger study, grounded in ethnography, aimed at examining texts and the role they play in realising the shared goals. The case in study was a Japanese multinational plant involved in car audio assembly. The objective was to gain insights into how texts are being shaped to meet the specific functions they were called on to serve; as well as how they shape the community's behaviour. The texts were being analysed for content, type and form. Results indicate the meeting of quality standards, and effective and efficient execution of tasks through the writer's deep awareness of the interplay of participant, shared purpose, shared beliefs, shared expectations and limitations in the environment.
\end{abstract}

Keywords: Writing texts; quality and efficiency of product and process; shared symbols; shared goals; shared values

\begin{abstract}
Abstrak. Terdapat perbezaan di antara penulisan teks untuk pekerjaan dengan penulisan teks untuk ilmiah. Walaupun banyak penyelidikan telah dijalankan untuk memenuhi kehendak pekerja dan majikan, penyelidikan yang meneliti secara kualitatif bagaimana sesuatu komuniti berinteraksi untuk mencapai matlamat bersama dan bagaimana teks memainkan peranan dalam hal ini masih berkurangan. Walaupun banyak telah diperkatakan selain daripada pengetahuan mengenai pembaca, tujuan dan kaedah penulisan, penulis juga harus mempunyai kesedaran mengenai budaya kerja sesuatu tempat kerja. Perkongsian nilai, norma, kehendak dan bahasa dipercayai mempunyai pengaruh dalam pembentukan teks. Setiap organisasi dikatakan mempunyai matlamat dan budaya kerja tersendiri dan teks dikatakan memainkan peranan dalam pencapaian matlamat tersebut. Kaji selidik percubaan ini adalah sebahagian daripada kajian etnografi yang lebih luas dan bertujuan mengkaji teks dan peranannya dalam pencapaian matlamat bersama. Kajian dijalankan di sebuah firma elektronik multinasional Jepun yang terlibat dengan pemasangan radio kereta. Tujuan kajian adalah untuk memahami bagaimana teks dibentuk dan membentuk kelakuan komuniti. Teks dianalisis dari sudut isi, bentuk dan jenis. Analisis menunjukkan pencapaian kualiti dan perjalanan proses secara efisien melalui kesedaran mendalam penulis berkenaan perhubungan di antara peserta, perkongsian matlamat, kepercayaan, kehendak dan kekangan di dalam persekitaran tempat kerja.
\end{abstract}

Kata kunci: Penulisan teks; kualiti dan efisyensi produk dan proses; perkongsian simbol; matlamat dan nilai

College of Science and Technology, Universiti Teknologi Malaysia International Campus, Jalan Semarak, 54100 Kuala Lumpur 


\subsection{INTRODUCTION}

Effective communication with customers and between co-workers has been universally recognized as crucial to the smooth and productive running of an organization. Equally important, too, is the recognition and acceptance of effective communication as an important area for human resource development. While this has been the thrust for the productive running and further expansion of workplace settings, there is a growing concern in the academia about whether academic and training programmes have also taken a similar course for human resource development in their bid to ease the transition of graduates from academic to workplace settings.

In communication, specifically the English Language communication, research into enhancing speakers'/writers' required skills for the workplace are increasingly gaining priority. The increasing number of needs surveys (Goh and Chan, 1993; Louis et al. 1991; Yeo. et al. 1994; Siti Hamin Stapa et al. 2008; Tg. Nor Rizan et al. 2008 ), ethnographic studies (Yates and Orlikowski, 2002; Stubbe, 1998; Ainol Haryati Ibrahim, 1993; Ainol Haryati Ibrahim et al. 1994; Hadina Habil, 1993; Morais, 1994; Masputeriah Hamzah et al. 1995; Khairi Izwan Abdullah et al. 1995; Anie Attan, 1998) and exploratory studies (Schneider and Andre, 2005; Ablonczy-Mihalyka, 2008; Scheeres and Iedema, 2003; Hovde, 2003) reflect the growing interest and concern among researchers and practitioners at tertiary institutions of the need to deliver courses that match learners' specific needs.

In attempting to address the issue of a need to deliver courses that match learners' specific needs and expectations, research over the years, have taken various angles. Some have attempted to determine and match what the specific needs are with workplace requirements; some have attempted to identify the causes of ineffective communication, specifically poor writing/oral skills; while some others have attempted to recognize the importance of good writing for career advancement. Anie Attan et al. (1993), in their study of the needs of trainees while on industrial training, found that the trainees were dissatisfied with the English Language training that they have received. Trainees had indicated that the tasks that they have had to perform in class were unlike those of real-world contexts. One trainee recounted her experience of having to write precise but short reports which were unlike those that she had been exposed to. Another, who shadowed the engineer in writing production manuals, reported the difficulty of coping with technical symbols, specialized expressions and lexicon with which he had had no prior knowledge, training and experience. To him, the industrial training was a 'window' to the real happenings in the real-world, an induction to workplace culture, expectations and challenges with which he has had to learn to accommodate in his quest to be part of the community.

Katz (1998) in her study laments the prevalence of poor writing in the workplace and blames both the education and the employer's organizational culture for the dismal state. She explains deficiencies in workplace writing exist, because firstly, schools had not prepared students for the writing they needed in the workplace; and secondly, new 
employees were asked to manage two unrealistic contradictory demands simultaneously, i.e., learn the conventions that will enable them to write appropriately and begin writing immediately. Redish (1989), and Fennick et al. (1993), like Katz, blame the employees' education and the lack of training for the poor workplace writing. Von Diether (1992), on the other hand, places the blame for poor writing in the hands of the management. Anderson's (1985) study on what survey research tells us about writing at work, however, did not yield any concrete conclusions except for a fact that writing does affect an employee's advancement. Smart's (1993) study, similarly supports earlier findings that good writing is a necessary prerequisite for a person's upward mobility in an organisation.

Although there is increasing awareness of the need to address the concern of a match between management demands and expectations with those of the employees' over the years, there is yet, adequate body of knowledge to inform researchers and practitioners about the working of the processes that had made possible the realization of organizational goals. There are questions requiring answers such as what type of texts do workers work with, what type of information is contained in those texts, what forms are used in meaning realisation, what considerations do the writers make when writing the texts, and many more.

In light of the questions stated above, the study attempts to examine the issue, in which an in-depth investigation of how documents are written within the specific context will be carried out. To facilitate the study, the following research question has been drawn up to guide the researcher in data collection:

Research Question: How do document writers make language selections and negotiate meanings for the attainment of shared organisational goals?

\subsection{THEORETICAL FRAMEWORK}

According to Halliday (1989), language is shaped by the functions it is called on to serve. In his notion of the functions of language, three metafunctions of language are identified. They are the 'thinking' or ideational function; the 'doing' or interpersonal function; and the textual, which does the function of ensuring that what is said is relevant to the context. The ideational function helps the reader/hearer to understand the processes being referred to, the participants in the processes, the relationship between one process and another, and the circumstances. The interpersonal function helps the reader/hearer to recognize the speech functions, the attitudes embodied in them and the rhetorical features associated with them. The textual function helps the reader/ hearer to understand topics and messages and helps establish coherence between one part of the text and another.

Halliday also explains that all use of language has a context, which is "the immediate environment in which a text is actually functioning" (Halliday and Hasan, 1989, p. 46). To Halliday, this notion of context of situation is used to explain why certain things are said or written the way they do on a particular occasion and in a given context. Three 
components of the notion of context of situation are identified to help explain the close relationship between the text and the context, i.e., the field of discourse, which defines the kind of activity taking place, in which language is seen as playing a part in describing the social action; the tenor of discourse, which refers to who are taking part in the activity, their status-role relationship and the speech roles they assume in the negotiations; and the mode of discourse, which refers to the symbolic organization of the text in terms of status and functions in the context.

According to Halliday, the context of situation, however, is only a part of the environment in which texts are constructed. There is a broader context, that of the context of culture, in which the texts are to be interpreted. This refers to certain ideas, assumptions, and practices that the participants in that particular setting observe and to which they attach special meanings to those social actions enacted on particular occasions. The texts that unfold on those occasions are not isolated documents but are culture-bound discourses acting to further the communication between the interlocutors. Thus, knowledge of the contexts of situation and culture help the participants/observers understand how texts shape and are systematically being shaped towards meeting social ends.

In describing language in use to meet specific ends, Bhatia (1993) suggests adoption of a model which is "rich in socio-cultural, institutional and organizational explanation" (p. 10). The model, 'Genre Analysis', proposed by Swales (1990), Bhatia believes, is useful for explaining form-function relationship. Bhatia interpreted Swales' 'genre' as "a recognizable communicative event characterized by a set of communicative purpose(s) which is mutually understood by the members of the professional or academic community in which it regularly occurs.' (p. 13). In analyzing Swales' 'genre', Bhatia highlights four aspects of the definition, i.e., communicative purpose, communicative event, constraints of choice of content and style, and exploitation of constraints to explain why texts are written the way they are. For example, the construction of a genre, he observes, is primarily determined by the communicative purposes it is intended to fulfill. Any change in purpose, he asserts, might give a different genre, even though there are other factors such as content, form, audience, channel, etc. that may influence it. Additionally, genres as communicative events, have assumed their conventionalized internal structure as a result of their members' knowledge of the purposes and goals of their specific community, their members' long training and experience within the community and the demands of the professional work. Thirdly, achievement of intentions, he observes, comes about as a consequence of the members' observation of the rules and conventions of standard practice within the boundaries of the genre. The use of specific lexico-grammatical resources for certain intentions, specific genres for certain kinds of meanings, certain expressions for realization of special meanings and certain positioning of rhetorical elements for certain effects, are some instances. Finally, genre writers use specialized genres to achieve certain desired effects in their texts, and that one needs to be familiar with the conventions of a genre in order to understand why certain writers write the way they do. 


\subsection{WORK CULTURE OF THE CASE IN STUDY}

Shared understandings and shared specific knowledge about the organization formed the basis for members' participation in the organization. Reality, as perceived by the members was acting in tandem with that understanding and internalization of that meaning subset for the duration of their specialised activities. The prime objective of the members' specialised activities was to meet the demands of the customers, both 'internal' and 'external' customers. The 'internal' customers were the communities at the immediate subsequent lines of production, while the 'external' customers were the communities who would finally 'consume' the product.

Timeliness and attention to quality were two important traits emphasized in the community. These were manifested in the demands for quality and efficiency at all stages of the members' specialized activities. The achievement of these was dependent on an efficient and effective communications system between the members. This was manifested in members' maintenance of a safe, clean and orderly work environment, attention to systematic presentation of information, attention to quality, attention to set targets and attention to discipline. The ' $5 \mathrm{~S}$ ' maxim, derived from the cumulative initial letter of the five rules of Japanese housekeeping, (Seiri \{sorting\}, Seiton \{arranging\}, Seiketsu \{maintaining\}, Shitsuke \{training\} and Seiso \{cleaning\}) became the work norm for members to observe in carrying out their daily activities. In observing the ' $5 \mathrm{~S}$ ' housekeeping rule, the Japanese management believe that if cleanliness and orderliness at the workplace were maintained, it follows that quality of product and process would automatically take care of themselves. The unwritten rule in the Japanese organization was for cleanliness and orderliness to be maintained at all times and for all members to assume shared responsibility for the upkeep.

Members also subscribed to shared values such as teamwork, prompt delivery, zero defect, quality, and interdependence of process and communities. Quality and work efficiency underpinned all work processes. Non-conformances, rejects and non-meeting of schedule dates were not tolerated as these entailed unnecessary costs, wastage and backlog. Strict observation of timelines was made through the time requirement embedded for the completion of each particular task, locally termed the standard time (ST). For example, given a standard time (ST) of thirty seconds to complete a certain task at a particular work-station, the member at the work-station must adhere to the time frame given. Similarly other members at other work-stations had a similar ruling to observe. Strict observation of this work requirement by all members would ensure the smooth running of the assembly processes. The spirit is in togetherness they work for the achievement of their set targets.

\subsection{RESEARCH METHOD}

For this article the researcher sampled two texts from two different departments of a Japanese multinational corporation, involved in the assembly of car audios, in Malaysia. 
These texts are the types that trainee engineers learnt to write while shadowing the trained engineers. In this case study, there were altogether as many as nine different types of written texts from four different departments for the entire production process. These were the Job Instruction Manual, Technician Report, End-of-shift Report, Memorandum, Trouble Countermeasure Report, Cause and Countermeasure Report, Rework Report, Production Instruction Manual and Technical Report. For the present purpose, only the Job Instruction Manual shall be investigated.

The Job Instruction Manual was the guide for lower rank machine-operator members of a particular department to refer to as a basis for accurate execution of their tasks to specified quality requirements. The Job Instruction Manual gives step-by-step instructions for a specific task to be carried out at a particular work-station. The end-product of this work-station, in turn, became the 'raw material' or input for the next work-station as it moves along the assembly line. At one particular assembly line there can be as many as ten work-stations, each being assigned only one part of the assembly process. In this study, the researcher sampled a text from the initial production process (belonging to the Printed Circuit Board Department) and another from the final production process (the Final Assembly Department) in an attempt to gain insights into the manner the writers (engineers) of the texts negotiate meaning through effective use of language for efficient and effective execution of tasks by the line operators.

The selected texts were analysed for type, content and form.

\subsection{ANALYSIS}

Figures 1 and 2 present the samples used in the study. Figures 1 and 2 present the two texts shown at one of the Printed Circuit Board and Final Assembly work-stations respectively. These were part of a longer text for the assembly of car audios. Text $\mathrm{A}$ represents a selection of sub-texts of the Printed Circuit Board Department, while Text B is a selection of sub-texts of the Final Assembly Department. These "how to" or procedural discourses told the actors/readers (line operators) how to complete a task through a series of ordered steps. The following examples explain how the writer accomplished his purpose.

Example 1: The first step told the actor to keep the mentioned specific location free of any residue for the mounting of the component. Effective command was achieved through imperative and content words in Bahasa Malaysia to ensure that the actor fully understands the task that he has to fulfill; the component, given a specialised code; and the object, solder, retained in the English form. It was noted that effectiveness of communication and quality and efficiency of performance were achieved through the first language of the line operator. Since over eighty percent of the line operators were Malays, all imperatives and content words were expressed in the Malay language. Production components, in turn, were identified by their specialized codes, such as IC2, etc. being symbols that members have had to internalise for speedy recognition and 
TextA

Job Instructions

(Printed Circuit Board)

Mounting 2

1. Bersihkan tempat IC2 dari lebihan solder

2. Pasangkan IC2 dan solderkan pada 3 penjuru kaki IC2 seperti rajah

3. Solderkan kesemua bahagian kaki IC2 secara rata dan bersih

4. Pastikan ianya tidak

- "wrong value"

- "reversed"

- "solder short"

- "dry solder"

- "tilted"

Figure 1 Job instructions (printed circuit board)

Text B

Job Instructions

(Final Assembly)

Mounting 1 Sila pakai armband dan sarung tangan

1. Ambil PCB $\times 14$ dan buangkan bahagian yang tidak dipakai dengan plier Pastikan plier anda tidak terkena $\mathrm{CN} 3$

2. Pasangkan insulating sheet ke chassis

3. Pasangkan $\times 14$ ke chassis

4. Bengkukkan ketiga-tiga lug chassis

Mounting 2 Sila pakai armband dan sarung tangan

1. Pasangkan "lead holder" ke "front chassis"

2. Buangkan "cover parallel lead"

3. Ambil "cassette mechanism"

4. Tutup "connector wire" ke "mecha"

5. Pasangkan "connector cassette mecha" ke "CN 14 di X 14"

6. Skrukan "cassette mecha"

7. Skrukan "PCB" ke "chassis"

Figure 2 Job instructions (final assembly)

performance of task. This was learnt through induction and in-house training courses, prior to the actor assuming his/her role. Objects such as solder, retained their English form, in recognition of universally accepted conventions of standard practice.

Example 2: The syntactic structure of the next sub-step follows a similar pattern. Interestingly, the second imperative solderkan was derived from the English form for object and given a Bahasa Malaysia suffix, and by doing so, turned it into a command (to join by using the substance). It was noted, in this instance, that the social rule for the use of the convent was changed to enable the actor to fully understand the task and to ensure that it was carried out as stipulated. The syntactic structure of the next substep follows a similar pattern and explanation. 
Example 3: The syntactic structure of sub-step 4 also assumes a similar pattern: imperatives in Bahasa Malaysia and expected conditions of actions in specialized English conventions. Again, it was noted that the text was being shaped in reference to the purpose (quality 'output') and participants, i.e., meaning negotiation in Bahasa Malaysia for full comprehension of instructions in task fulfillment. It was also noted that for the task to be completed to expected standard, all members had to have good shared knowledge of these conventions whose forms in English have become shared knowledge of the community. The actor was expected to know all these states of nonconformances and was also expected not to produce such non-conformances such as missing, reversed, tilted, solder short, dry solder and leg bent. Apart from the text being shaped to meet a certain goal, the syntactic structure, in this instance, also determines and shapes the behavior of its community.

A similar pattern of meaning negotiation (imperatives and content words in Bahasa Malaysia, shared system of knowledge in English and components in specialized symbols) was observed in the set of instructions in Text B. The following examples explain how the writer accomplished his purpose.

Example 1: Step 1 of Text B began with a stipulation of the environments in which the Job Instructions were to be carried out. This was accomplished in Bahasa Malaysia for full comprehension by the actor of the need to adhere to work requirements. Similarly, directives for correct tasks completion were in Bahasa Malaysia; tools in English; and boards and components in specialized symbols. The syntactic structures of the next three sub-steps also follow a similar pattern and explanation, i.e., imperatives and content words in Malay, tools and parts in English.

Example 2: The syntactic structures for the next mounting stage also follow a similar pattern and explanation, i.e., imperatives and content words in Bahasa Malaysia; tools and parts in English; and components and locations in specialized symbols.

\subsection{DISCUSSION}

The uniqueness of the texts, in the above examples, merits discussion in light of factors such as characteristics of the actors (operators), the expectations of the stakeholders (the firm), the purpose and the rules of negotiation. The responsibility of producing a readable text, one that enables the actors to follow and perform the series of ordered tasks, it was noted, is on the writer. $\mathrm{He}$, as well as being competent with the mechanics of language transfer (from English to Bahasa Malaysia) has also to be sensitive to the demands of the community and the organization, the participants and the rules of negotiations.

First, the community and stakeholders' demands for quality and efficiency to be achieved, which invariably meant that time, money, manpower and material resources 
have to be utilized optimally for maximum returns, and, outputs to be of uncompromising standards. In meeting the expectations of quality and efficiency of product and process, the specific demand to keep cost down in production and the need for meanings to be understood in the most efficient, accurate and effective manner, i.e., the What concern of the text, is conveyed through a code-mix of Bahasa MalaysiaEnglish and specialised symbols which are shared knowledge of the community. A large part of the text is shaped in Bahasa Malaysia in view of the composition of the participants and the purpose of the interaction. This is reflected in the 'action' part of the discourse, in which the actor is asked to carry out a particular action for a given step, expressed in the native language of the actor. Such actions are realized through imperatives and support information, such as bengkukkan, buangkan, skrukan, solderkan, pasangkan, bersihkan where the morphological affixation kan is used as emphasis and a command for someone to do a certain action; and support information such as penjuru kaki, kesemua bahagian kaki, ketiga-tiga giving details for the actions.

Alternatively, English was used for naming objects, parts and tools, such as solder, insulating sheet, chassis lug chassis lead holder, front chassis, cover parallel lead, cassette mechanism, connector wire, mecha, pliers; and for states of conditions of processes such as missing, reversed, tilted, solder short, dry solder, leg bent, wrong value, leg outs, etc. These are retained as they are accepted conventions of standard practice. Other features include use of specialised symbols to refer to specific components and boards, such as IC for integrated circuit, $\mathbf{N}$ for screw, $\mathbf{X} 04$ for sub-power amplifier board, X 09 for amplifier board, etc. and different locations are identified by a set of symbols, such as $\mathbf{C N ~ 3 , ~ C N ~}$ 14. These have been designed by choice for greater efficiency of work.

Second, the code-mix discourse is also shaped in consideration of the type and characteristics of the participants. Since over eighty percent of the actors are ethnically Malays, speak mainly Bahasa Malaysia and had minimum primary education, the onus is on the writer to select symbols that could best be easily understood and transacted. As shown, a large part of the texts is in the language of the actor while standard practice forms are retained in English. As recruits, the actors are put on a three-month probation period and given training to recognize the symbols and to carry out the tasks correctly. Training is by the learning-by-doing type, in which they will be exposed to the texts and tasks. Through intensive practice of repetitive work and association with the respective symbols, accuracy is accomplished. With minimum education and common native language background, the Bahasa Malaysia-English discourse of Job Instructions answers the To Whom concern of the text. This aspect of language selection skill is a necessary prerequisite for writers to have.

The third is the rules of negotiation. This factor answers the How concern of the text, in which was shown how texts shape and are being shaped to match the demands of the situation and function, defined in terms of the production of quality outputs, of given quantities, within a stipulated time frame and with minimum wastage. In the Job Instructions, unlike other procedural texts, such as those of Do-It-Yourself kits and Product 
Instruction Manuals, the actor in this text type has to be an initiated member of the community, to be able to understand and to correctly perform the series of actions within the stipulated standard time. With the end in mind, writing up of the texts involves making choices, on the part of the writer, of which are relevant to the social context in which the meaning is to be conveyed. This is achieved through deep awareness of the shared goals and expectations that every member in the organisation holds, i.e., quality product and efficient service; and effective communication, i.e., negotiation of meaning in the most efficacious manner; notions proposed by Halliday and Hasan (1989) as mentioned earlier. Effective communication is effected, in the above context, by a codemix of Bahasa Malaysia-English and specialized symbols in which social rules dictate violation of conventional rules of negotiation for achievement of desired outcomes. This aspect of meaning negotiation skill is highly required in writers.

\subsection{CONCLUSION}

On the basis of the above data and analysis, though limited to only one type of many different text type in an organization, it appears that workplace texts are written differently from those that learners have been trained to. Given the many different type of texts in an organization and the prevalence of the different type of organizations of differing specialty, it seems language trainers are faced with a colossal task ahead. What are the different type of genres used in writing texts? Do trainers have to teach the different type of genres adopted in the different work settings? Do trainers have the exposure and required skills to train the learners? Do training institutions have the resources (capital, human and time) for this purpose?

The implications of this workplace feature on teaching/training seem enormous; and for that, more in-depth studies are required. For a start, based on the experiences of trainees on industrial training, a reasonable strategy is to propose a longer period of industrial training to enable the trainees to have adequate exposure to the workplace culture and to sample the different tasks they are asked to perform and to perform them to a given satisfactory standard. Work shadowing in this regard is very appropriate and highly relevant to learners attempting to be absorbed into the organization.

\section{REFERENCES}

Ablonczy-Mihalyka, L. 2008. Workplace Discourse between People with Different Cultural Backgrounds. http://hej.sze.hu/LIN/LIN-081029-A.

Ainol Haryati Ibrahim et al. 1994. An Ethnographic Study of the Target Discourse Community. Research and Consultancy Unit, Universiti Teknologi Malaysia, Skudai Johor.

Ainol Haryati Ibrahim. 1993. A Case Study of the Manufacturing Industry: The Ethnographic Way. Unpublished M Sc. Thesis. University of Aston.

Anie Attan. 1998. English in Industry: A Study of Language Choice in Two Electronics Firms in Malaysia. Unpublished $\mathrm{PhD}$ Thesis Submitted to the University of Malaya.

Anie Attan, Louis, A. F. and Khairi Izwan Abdullah. 1993. Designing Quality Service Profiles to Meet Customer Needs. Paper presented at the Seminar on Research and Development, Skudai, Johor, Universiti Teknologi Malaysia. 
Bhatia, V. K. 1993. Analysing Genre: Language use in Professional Settings. London: Longman.

Fennick, R., M. Peters and L. Guyon. 1993. Solving Problems in Twenty-first Century Academic and Workplace Writing. English Journal. 82: 46-53.

Goh, S. P. and S. W. Chan. 1993. The Use of English in the Commercial Sector of the Malaysian Economy: Perspectives from Potential Employers and Employees. ESP Malaysia. 1/2: 128-147.

Hadina Habil. 1993. The Application of the ISO 9000 Series of Standards in Language Teaching as a Quality Control Measure: An Investigation into the Applicability of the Service Quality Loop as a Model for ESP Programme Evaluation. Unpublished M Sc. Thesis. University of Aston.

Halliday M. A. K. and R. Hasan. 1989. Language, Context and Text: Aspects of Language in a Social Semiotic Perspective. Oxford University Press.

Hovde, M. R. 2003. How Workplace and Academic Engineering Written Communication Abilities Differ: A Foundation for Communication Assessment. Sectional Conference Paper. American Society for Engineering Education April 4-5. http://www.asee-4ilin.ors/doc.

Katz, S. 1998. The Dynamics of Writing Review: Opportunities for Growth and Change in the Workplace. Stanford, CT: Ablex Publishing Corporation.

Khairi Izwan Abdullah, Abdul Halim A. Raof, A. F. Louis and Zubaidah Awang. 1993. ESP in Malaysia: An Overview. ESP Malaysia. 1/1: 61-72.

Khairi Izwan Abdullah, Abdul Halim A. Raof, Louis, A. F. and Masputeriah Hamzah. 1995. Towards a Framework for Curriculum Design in ESP. ESP Malaysia. 3/1: 13-26.

Louis, A. F. Shaikh, A. Karim Shaikh, A. Rahman and Zainal Abidin Ahmad Mohd Noor. 1991. Investigating University Students' Needs for English Language Proficiency as Undergraduates in Universiti Teknologi Malaysia and as Future Technocrats. Research and Consultancy Unit. Universiti Teknologi Malaysia.

Masputeriah Hamzah, Khairi Izwan Abdullah, A. Halim A. Raof and A. F. Louis. 1995. Designing Learning Materials for Civil Engineering Students. ESP Malaysia. 3/2: 118-135.

Morais, E. 1994. Malaysian Business Talk: A Study of the Pattern of Conflict and Non-conflict in Verbal Interactions. Unpublished $\mathrm{PhD}$ Thesis Submitted to the University of Malaya.

Scheeres, H. and R. Iedema. 2003. Learning to Talk: From Manual Work to Discourse Work as Self-regulating Practice. http://www.emeraldinsight.com.

Schneider, B. and J. A. Andre. 2005. University Preparation for Workplace Writing: An Exploratory Study of the Perceptions of Students in Three Disciplines. The Journal of Business Communication, April 2005. http://www.entrepreneur.com/tradejournals/article/13/20/068.html

Siti Hamin Stapa, Tg. Nor Rizan Tg. Maasum, Rosniah Mustaffa and Saadiyah Darus. 2008. Workplace Written Literacy and its Effects on The Curriculum. Gema Online Journal of Language Studies. 8(1).

Stubbe, M. 1998. Researching language in the workplace: A Participatory Model. Australian Linguistic Society. http://emsah.uq.edu.au/linguistics/als/als98

Tg. Nor Rizan Tg. Maasum. Kemboja Ismail, Norwati Yusoff and Saadiyah Darus. 2008. Executives' Written Literacy Practices at the Workplace. Paper Presented at the Language for Specific Purposes Conference, 8-9 April 2008.

Yates, J. A. and W. Orlikowski. 2002. Genre systems: Structuring Interaction Through Communicative Norms. http://www.entrepreneur.com/tradejournals/article/13/20/068.html

Yeo, B. K. et al. 1994. Restructuring of the English Language Proficiency Programme at Universiti Kebangsaan Malaysia. An Analysis of the Language Needs of Undergraduates, Universiti Kebangsaan Malaysia. 